\title{
CMAJ 2011 election survey: health transfers
}

$\mathrm{T}$ here probably isn't a provincial finance minister or health administrator in Canada who isn't grinning like a Cheshire cat.

When the writ dropped for the 2011 federal election, no one expected any of the political parties to spell out their intentions for annual transfer payments for health care made to the provinces after 2014, once the current intergovernmental health accord expires.

In fact, conventional wisdom held that it would be foolish to do so, given that there was no way to forecast what the economy might look like or how much the government might be able to afford. Moreover, experts argued that any promise to maintain unconditional $6 \%$ annual increases in health transfers ad infinitum would put the government of the day behind the eight-ball at the negotiating table. Why would any province agree to any manner of accountability measures if they knew the federal government would open its coffers come what may?

Conventional wisdom, though, quickly proved wrong as the Conservative, Liberal and New Democrat parties indicated that the $6 \%$ escalator clause will be maintained post-2014 (www .cmaj.ca/earlyreleases/4theRecord.dtl). They essentially affirmed their stances in response to a health spending question in CMAJ's 2011 election survey (see below).

But each of the vows come with something on the order of a rider.

The Conservatives have been careful to limit their escalator commitment to that specified in the recent federal budget (www.budget.gc.ca/2011/plan /Budget2011-eng.pdf). In that budget, which was not approved by Parliament, an increase in federal transfers for health care is prescribed for exactly two years after the accord expires, i.e., to \$44.7 billion 2014-15 and \$47 billion in 2015-16. When asked if that constitutes a commitment ad infinitum, a Conservative spokesman carefully restated that the escalator commitment is

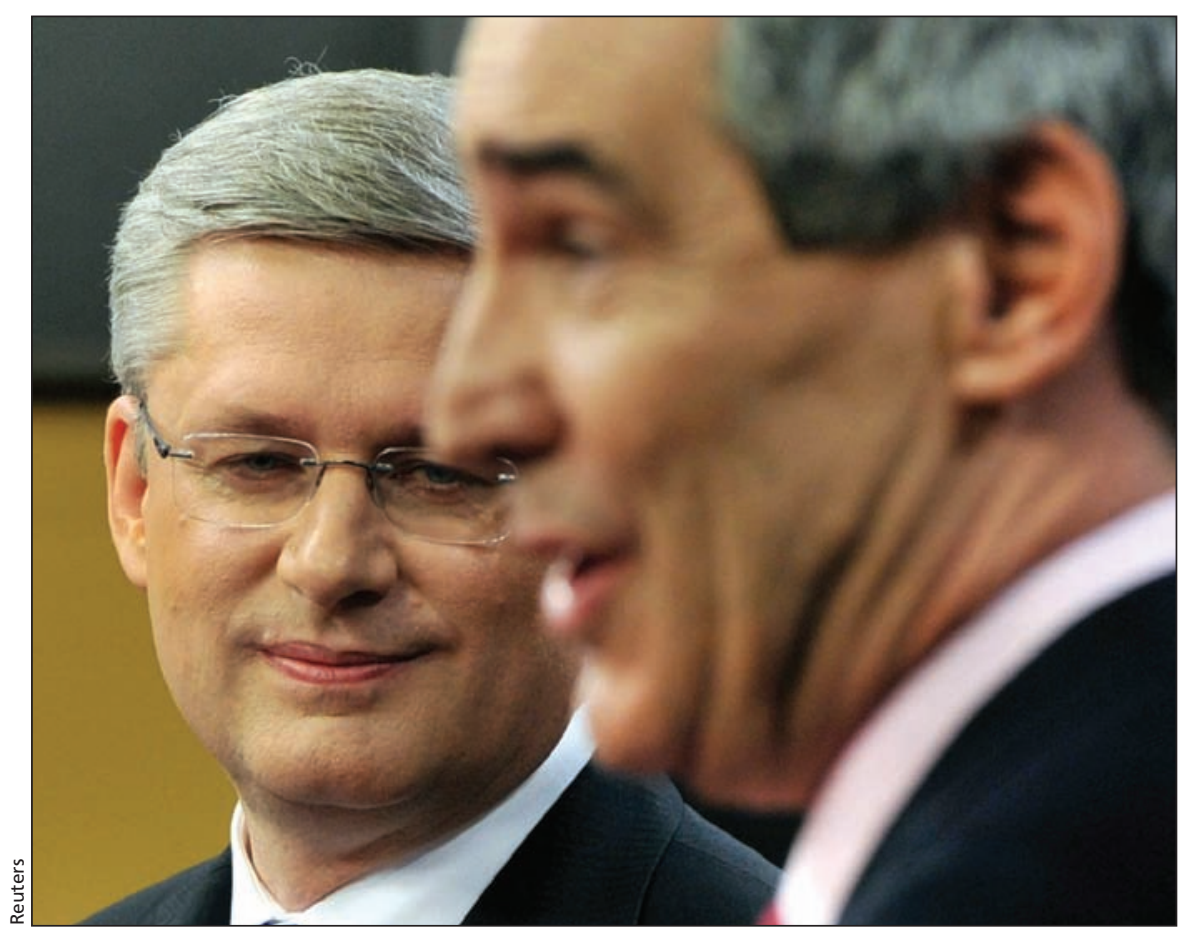

Conservative Party Leader Stephen Harper observes Liberal Party Leader Michael Ignatieff during the Apr. 12 English-language federal election debate.

precisely that specified in the budget. Translation: the promise doesn't necessarily extend beyond 2015-16.

The Liberals indicate in their survey response that they will seek to link an ongoing $6 \%$ increase in transfers to some manner of accountability measures. "All governments must do a better job of being accountable to Canadians for results, value for money and the quality of healthcare service across the country. While provinces and territories are struggling with escalating costs, it's far from clear that more money is the only solution."

The New Democrats also attach a rider to their escalator commitment, to wit, that recipient provinces must make a "clear, monitored and enforced commitment to respect the principles of the Canada Health Act and to the integrity and modernization of health care."

The Bloc Québécois, meanwhile, essentially asserts that accountability measures of any manner are unwarranted as health care falls under provin- cial jurisdiction and transfers should be unconditional. They also say they will work to see that transfers are "significantly" enhanced.

With the three national parties having committed to an escalator clause post2014 , attention shifted to the problematic issue of paying for it. The issue was front-and-centre in the Apr. 12 English language leader's debate.

Prime Minister Stephen Harper cast the affordability issue strictly within the parameters of Conservative economic policy: to wit, that tax cuts grow the economy and make social programs possible. "Let's be clear about the choices. We want to keep our economy on track so we can continue to fund and increase funding for our health care system. The choice Mr. (Liberal leader Michael) Ignatieff puts before you, and the other parties, that you somehow have to choose between the military and health care. You have to choose raising taxes if you want to keep benefits. It's a false choice. The Liberal party, when it 
was in office, raised taxes. And they cut health care. And they cut education and they cut pensions and they cut all these things because when they raise taxes, they hurt economic growth and they hurt the economy. That is a false choice. We're all moving forward together. We need a low-tax future where we can continue to fund and increase funding for our health care system."

Ignatieff countered that the cost of maintaining a $6 \%$ escalator clause could be easily absorbed. "You peg the corporate tax rate at $18 \%$, you save $\$ 6$ billion. You put those jets out to competitive tender, you save more billions. You stop building those megaprisons, you save still more billions. That allows you to invest $6 \%$ to improve Canadian health care. This is choice time. Mr. Harper is offering you fantasy economics. He cannot explain how he's going to sustain Canadian health care. We can."

New Democrat leader Jack Layton said "it's going to be about making choices. Mr. Harper is trying to tell us tonight that one can have absolutely everything: huge tax cuts, huge expenditures on jets and continued increases in health spending. This isn't the old Stephen Harper talking. This is the one who's now been affected by the Ottawa culture, I have to say. But it does mean making some choices and some things we will not be able to do if we're going to fund our health care."

Bloc Quebecois leader Gilles Duceppe, meanwhile, retreated to oftrepeated ground, arguing that "there is too much money in Ottawa" and more of it should be shovelled to the provinces. - Wayne Kondro, CMAJ

Survey question: Do you favour continuation of the existing formula (a $6 \%$ annual increase) for health transfers beyond 2014 once the current health accord expires?

Conservative response:

No response. Rather than participate in CMAJ's 2011 election survey, the Conservatives forwarded a weblink to their party platform. Asked what the rationale was for declining participation, party spokesperson Ryan Sparrow says the weblink constitutes a response to the survey. "That response is the response from the campaign."

\section{Liberal response:}

"With the federal-provincial-territorial Health Accord expiring in 2014, a new funding arrangement must be a central priority for the next federal government. At this pivotal moment, a great deal is at stake for Canadians, but the Harper government has demonstrated little interest.

In contrast, a Liberal government will be at the table for Canadians. We will come equipped with a collaborative approach and the objectives that drive our health and healthcare platform: relieving pressures on today's Canadian families, improving health outcomes, improving quality in the healthcare system, and containing long term costs.

The Government of Canada is a major funder of healthcare through transferred tax points and cash transfers to provinces and territories. All governments must do a better job of being accountable to Canadians for results, value for money and the quality of healthcare service across the country. While provinces and territories are struggling with escalating costs, it's far from clear that more money is the only solution.

Governments must ensure we're getting full value for the money already in the system. Management improvement and innovation, advanced through much more effective dissemination of best practices nationally and internationally, promise to contain costs and improve service to Canadians at the same time.

Canada was once thought to have one of the best health care systems in the world. Renewed commitment at the federal level, and effective partnership with provincial and territorial govern- ments and other health sector leaders can make that true once more."

New Democrat response:

"A New Democrat government would negotiate a new ten-year health accord with the provinces and territories in 2014. The accord will guarantee a continued strong federal contribution — including the 6 per cent escalator to Canada's public health care system - in return for a clear, monitored and enforced commitment to respect the principles of the Canada Health Act and to the integrity and modernization of health care. Additionally a New Democrat government led by Jack Layton would work with provincial and territorial partners to, promote a clear commitment to the single-payer system; take appropriate steps to replace fee-for-service delivery; reduce the costs of prescription medicines for Canadians, employers and governments and extend coverage to out-of-hospital services like home care and long-term care."

Bloc Québécois response:

"L'entente de 2004 reconnaissait qu'en matière de soins de santé, c'est le gouvernement québécois qui a pleine juridiction et que le Québec a une obligation non pas de rendre des comptes à Ottawa mais aux Québécois et Québécoises.

Le Québec n'aurait pas dû avoir à se battre pour obtenir sa 'clause Québec'. La santé relève spécifiquement et entièrement du Québec et des provinces et il est tout à fait normal que le Québec puisse obtenir un financement inconditionnel. La santé a toujours été de compétence québécoise, un fait que l'entente de 2004 n'a fait que confirmer.

Comme vous vous en doutez, le Bloc Québécois travaillera afin que la prochaine entente sur la santé conserve, minimalement, la 'clause Québec' et que les transferts soient bonifiés de manière significative."

CMAJ 2011. DOI:10.1503/cmaj.109-3865 